\title{
The Relationship Between Volatility and Sovereign Credit Risk in the Emerging Markets: A Nonlinear ARDL Approach
}

\author{
Fatih YiĞiTT ${ }^{1}$ Fuzuli ALIYEV ${ }^{2}$
}

\begin{abstract}
This study investigates the short- and long-run nexus between the volatility index of VIX and sovereign credit risk represented by CDS spread in emerging markets, namely Turkey, China, Russia, Brazil, and Mexico. The emerging markets are at the center of investors' interest due to high return opportunities. The relationship between volatility and sovereign credit risk has been studied many times via linear models. However, financial series exhibit asymmetric dynamics, as volatility clustering, excess kurtosis, and others. Thus, we use nonlinear autoregressive distributed lags (NARDL) analysis to capture nonlinear relations between the volatility and the sovereign credit risks of these countries by using daily data from 04.01.2010 to 29.11.2019. The bounds test of the NARDL model confirms the cointegration between VIX and CDS spreads of the countries under study. The analysis of estimated NARDL parameters shows that negative shocks of the volatility index have a long-lasting impact on CDS spreads. Chinese CDS spread are more sensitive to VIX index changes in the short run. The effect of a decrease in volatility on Russian CDS spread is higher than the effect of an increase. Turkish and Brazilian CDS spreads are more reactive to increase in the VIX, whereas Mexican CDS is less sensitive. These findings show that investors, arbitrageurs and speculators should consider global indicators when taking a position on sovereign bonds of emerging markets.
\end{abstract}

JEL Classification: C22; F65; G15

Keywords: Volatility; Credit Default Swap; Asymmetry; NARDL

\section{INTRODUCTION}

In the late 1990s, we have witnessed many sovereign debt crises which caused the global financial crisis. Since the Mexican crisis in 1995, and particularly after the 1998 Russian default, sovereign debt crises have become the nightmare of the financial markets. Sturzenegger and Zettelmeyer (2006) document sovereign defaults in detail and discuss the changes in international financial architecture. Sovereign credit risk gain importance with the European sovereign debt crisis during the period 2010 to 2012 and the decrease of US debt in 2011 (Jeanneret, 2015).

Especially emerging countries need external debt to finance government expenditures. As these countries borrow externally, their credit risk is very important since it directly affects the ability of a country to access global debt markets. The yield spread, as an indicator of borrowing cost, is the difference between the interest rate and the rate offered by the US Treasury for the same maturity. All else equal, the country which has more volatile fundamentals will experience more likely default. This risk will cause a higher yield spread on its bonds (Hilscher \& Nosbusch, 2010). The difference of emerging sovereigns from other high-yield borrowers is that financially distressed countries do not liquidate their assets but may restructure their debts.

Several variables have been used in the literature as a proxy of sovereign credit risk. The first and the main group of studies use credit derivative spread as an indicator of sovereign credit risk. Another set of studies consider credit ratings to determine the sovereign risk determinants. Besides the mainstream, only a few 
studies make an effort to construct new sovereign risk indexes. For example, Agliardi, Agliardi, Pinar, Stengos, and Topaloglou (2012) derive an optimal risk index for emerging countries by considering different political, financial and economic risk factors, and argue that the index outperforms the other sovereign credit risk indicators.

The credit default swap (CDS) is the simplest, commonly used, and most liquid credit derivative which provides protection to the bondholders against credit risk. The credit derivatives market reached a huge amount after the innovation of CDS in the late 1990s. At the end of 1996the CDS, market size accounted for around $\$ 40$ billion. Before the global financial crisis, it reached $\$ 62.2$ trillion by the end of 2007. After the financial crisis of 2008, the total outstanding CDS amount decreased to the level of $\$ 31.22$ trillion as of mid-2009 (Eyssell, Fung, \& Zhang, 2013).

The second group of studies considers credit ratings as the indicator of sovereign credit risk. Larraín, Reisen, and Von Maltzan (1997) mention the importance of the credit rating industry to shape investor decisions by reducing information asymmetry. Their findings indicate that capital inflows are significantly influenced by modifications of credit ratings in emerging markets. The announcement of a negative outlook decreases the investments in sovereign bonds of emerging countries.

There are also some studies that investigate the relation between spreads and credit ratings. Theoretically, both the spread and credit rating are related to the same publicly available information. If it is true, we would not observe any effect of credit ratings on spreads. However, many studies conclude that CDS spreads are affected by rating announcements (Ballester \& González-Urteaga, 2017). Ismailescu and Kazemi (2010)analyze the impact of sovereign credit ratings announcements on the CDS spreads and the spillover effect to other emerging countries between 2001 and 2008. They indicate that positive events affect the CDS spreads significantly. They also provide evidence about the ability of CDS spreads to estimate the probability of a negative credit rating event. Recently, Ballester and González-Urteaga (2017) examine the effect of credit ratings on sovereign credit risk in six Latin American countries using the data from 2004 to 2014. They reveal the contagion effect of credit rating announcements to CDS spreads of neighboring countries in the same region. On the other hand, Cantor and Packer (1996) show that the disagreements on sovereign risk evaluation between agencies comparing Moody's and Standard and Poor's ratings. They also conclude that the market disagrees with the agencies and is more pessimistic than the agencies about sovereign credit by examining spreads and ratings.

A group of studies investigates the co-movement of credit derivative spreads, bond spreads, and stock prices. Chan-Lau and Kim (2004) address the equilibrium price nexus between credit derivatives, equity, and bond markets for sovereign issuers by extending Merton (1974)'s theory from company to sovereign issuers. According to this theory, the value of assets is restricted by the liabilities and default will occur when the value of assets descends below the debt value. Therefore, the higher debt to asset ratio means higher default risk. Merton (1974) concludes that equity and bond prices are positively correlated and adjust simultaneously to new information. Chan-Lau and Kim (2004) show that CDS and bond spreads converge in eight emerging countries over the period March 2001 and May 2003. They couldn't find any relationship between bond and equity markets and attribute this result to the inadequateness of linear cointegration analysis to catch the relationship. Chan, Fung, and Zhang (2009)examine the relationship between sovereign CDS spread and the stock prices in seven Asian countries over the period of January 2001 and February 2007. They found a strong negative relationship in most of these countries.

Investors who want to invest in different financial markets firstly view the CDS spreads of the countries to be sure about the risk that they may encounter. CDS spreads are crucial for emerging markets which need to encourage foreign investors. However, many empirical studies show that CDS spreads are affected by global factors, not country-specific factors. So, it is an important question how much the global factors affect the CDS spreads. Emerging markets are attractive to international risk-seeking investors due to high returns associated with high risks and being an option for portfolio risk diversification (Harvey, 1995). The characteristic dynamics of emerging markets differ from developed markets in a way that the emerging markets exhibit higher volatility. And they have faster and sharper price falls than developed markets (Patel \& Sarkar, 1998). These asymmetries should be modeled with nonlinear models. Thus, examining possible asymmetries in the dynamics of these selected emerging markets is significant for both academicians and market practitioners.

The aim of this study is to explore possible asymmetries in the short- and long-run relationships betwe- 
en 5-year CDS of selected emerging countries and the VIX index. The study argues that sovereign credit risk is highly related to global factors and the change in sovereign credit risk could be explained with these factors, here we focus on the volatility index of VIX. Especially for emerging countries, country-specific factors would be less important than those global variables. Secondly, most of the studies ignore the asymmetric relationship between sovereign credit risk and its determinants. This study differs from others considering the non-linear relationship and contributes to the literature in this way as well. Thirdly, our study covers a relatively long time horizon and daily data to reveal asymmetric dynamics between variables. Lastly, the set of emerging countries under study-China, Russia, Brazil, Turkey, and Mexicoare important actors in their regions, thus the findings may be a precedent.

The remainder of this paper proceeds as follows: Section 2 reviews the literature; Section 3 describes the data and methodology. Section 4 discusses the estimation results and the last section is the conclusion.

\section{LITERATURE REVIEW}

There is a large empirical literature about the determinants of sovereign credit risk. The literature review section would cover only the studies which use credit spreads to investigate the sovereign credit risk. A number of studies mention the importance of the economic condition of borrowers in the determination of credit risk and bond spreads. Maltritz and Molchanov (2014) investigate the political and economic determinants of sovereign credit risk for both emerging and developed countries. The study suggests that external debt to GDP ratio, and GDP growth affect the credit risk in both emerging and developed countries. Foreign exchange reserves to imports ratio, debt service ratio, and history of recent defaults significantly affect the credit risk in emerging countries whereas developed countries are influenced by openness, import growth, trade freedom, and inflation.

Sovereign credit risk and bond spreads depend not only on the economic condition of borrowers and also on the risk aversion behavior of investors (Borri \& Verdelhan, 2011). The determinants of creditworthiness of four South American countries are investigated by Weigel and Gemmill (2006) using monthly Brady bonds data from 1994 to 2001. The distance to default variable is estimated for each country and the findings indicate that only a few factors may explain \%78 of the credit risk of each country. The regional factors explain $45 \%$ of the variance while country-specific factors clarify only $8 \%$ of the variance in credit risk. They conclude that $25 \%$ of the variance is explained by US stock market returns. Pan suggests that there is a strong covariation between the CDS spreads of Korea, Turkey, and Mexico which have different characteristics and credit ratings. They suggest that global factors have a more significant impact on CDS spreads rather than the fundamental of these countries using the VIX index as an indicator of global risk factors. They indicate that the economic growths of the countries from different regions are affected by spillovers of US economic growth. Remolona, Scatigna, and Wu (2008) focus on components of sovereign credit risk and pricing the risk. They consider the country fundamentals and risk aversion of investors as the determinants of credit spreads. Empirical evidence is provided that global risk aversion is the main factor of sovereign credit risk.

Hilscher and Nosbusch (2010) investigate the relationship between country-specific and global macroeconomic factors and sovereign yield spreads of 31 emerging countries using the Emerging Bond Index Global (EMBI) between 1994 and 2007. Their studies find that macroeconomic fundamentals have significant effects on spreads. Furthermore, their findings show that the rate of exports prices to imports prices, volatility of terms of trade has a highly significant effect on spreads. The higher terms of trade indicate the ability to generate dollar incomes from exports and it may be used to pay off the debt. Longstaff, Pan, Pedersen, and Singleton (2011) comprehensively try to determine the nature of sovereign credit risk using broad CDS data of 26 countries both developed and developing. According to the findings, they attribute the majority of credit risk to global factors. The variation in sovereign credit spreads is found more related to the US market rather than local economic factors. They conclude that the commonality in sovereign credit spreads across countries is related to the risk pricing of marginal investors with a global portfolio. Eyssell et al. (2013) examine the determinants of CDS spreads in China over the period 2001 to 2010. They conclude that both country-specific factors and global factors affect CDS spreads in terms of levels and changes. They report that the global factors have become important in recent years while the country-specific factors are more relevant in earlier years. Jeanneret (2015) proposes a structural model of sovereign credit risk which determines the timing of default and the optimal debt policy. It is determined that this approach explains most of the daily variation in both European and emerging 
countries. The findings indicate that the global factors affect the sovereign credit risk significantly. The spreads are influenced by US market uncertainty in emerging countries and Euro-zone factors in European countries.

Figuerola-Ferretti and Paraskevopoulos (2013) use an extensive data set of three maturity categories (3-, 5- and 10 years) of iTraxx indexes and their individual CDS components, to investigate the nexus between VIX and the European CDS markets. Both assets classes are cointegrated and price discovery is defined by the relative level of trading activity in both markets. A simple equilibrium framework shows how slow adjustment of imperfectly integrated markets can be exploited to obtain arbitrage profits. The main contribution relates to the exploitation of VECM dynamics to gain profits by investing in VIX futures and the most liquid iTraxx index. Ricciardi (2016) investigates the cointegration between CDS and VIX indices. He tests for cointegration between volatility index and credit default swap indices utilizing the Johansen test. He finds cointegration through most of the period under study. He uses VECM to define the Gonzalo-Granger measure and finds that the volatility index leads credit default swaps in the price discovery process. This result supports the use of a unidirectional pairs trading strategy. Shahzad et al. (2017) study asymmetries in the short-run and long-run relationships between the 5-year CDS index spreads and some macroeconomic and financial variables as industry stock indices, the 5-year Treasury bond yield and others. They report that selected variables' positive and negative shocks have a differential impact on the industry CDS spreads. Chuffart and Hooper (2019) explore the impact of oil price returns on the sovereign CDS spreads for two main oil producers - Russia and Venezuela. They find that crude oil price and its volatility are significant determinants of sovereign debt.

Most of these studies examine the symmetric relations between sovereign credit risk and global indi- cators. However, this study contributes to the literature considering the asymmetric dynamics between these variables. Moreover, a longer time span and a broad set of emerging countries are utilized.

\section{DATA AND METHODOLOGY}

\subsection{Data}

We study 5-years sovereign daily CDS spreads and VIX data for the period of 04.01.2010 - 29.11.2019. The CDS spreads of the following emerging markets -China, Russia, Brazil, Turkey, and Mexico- and CBOE Volatility Index (VIX) derived from S\&P 500 options are used. As noted in the introduction, emerging markets are of greater importance for international investors due to their high return possibilities. Thus, we focus on theE7 countries, except India and Indonesia due to the missing data. CDS series is denoted with the country abbreviation in the subscript. The data is obtained from the Bloomberg database. A few missing data in the series are log-linearly interpolated. The summary of descriptive statistics of the series is exhibited in Table 1. Some of these variables have positive skewness as well as high values of kurtosis, implying that an asymmetric model is appropriate.

The distribution of CDS spreads of these countries, and the VIX index deviates from normality with the excess kurtosis in some series and positive skewness. These facts imply asymmetry. Heavy tailed leptokurtic distribution of the Russian, Brazilian, Turkish and Mexican CDS series implies the spreads are more concentrated around the mean. Based on the Jarque-Bera statistic, we reject the null hypothesis of normality for all series at $1 \%$ significance level.

\subsection{Methodology}

Financial time series have characteristics of asymmetry, especially those of emerging markets due

Table 1: Descriptive Statistics

\begin{tabular}{cccccccc}
\hline Series & Std.Dev. & Mean & Median & Skewness & Kurtosis & Jarque-Bera & JB Prob \\
\hline VIX & 5.647 & 16.885 & 15.510 & 1.747 & 6.901 & $2,851.529$ & 0.000 \\
\hline CDS_CH & 26.702 & 83.298 & 78.693 & 0.690 & 3.181 & 185.723 & 0.000 \\
\hline CDS_RU & 87.087 & 197.977 & 168.424 & 1.782 & 6.947 & $3,045.556$ & 0.000 \\
\hline CDS_BR & 86.592 & 193.644 & 166.783 & 1.597 & 5.419 & $1,728.870$ & 0.000 \\
\hline CDS_TR & 81.229 & 233.974 & 214.799 & 1.236 & 4.522 & 908.009 & 0.000 \\
\hline CDS_MX & 27.380 & 122.328 & 116.710 & 0.653 & 3.429 & 203.761 & 0.000 \\
\hline
\end{tabular}


to transaction costs, markets frictions among other reasons (Aliyev, 2019). The descriptive statistics of the series under study sign about asymmetry in the series. We study the following model between CDS spreads and the VIX index:

$$
C D S=c_{0}+c_{1} V I X+\varepsilon_{t}
$$

where CDS is the credit default swap spreads of the selected emerging markets under the study, and VIX is the CBOE volatility index derived from S\&P 500 options. The finance theory suggests that a sovereign CDS spread increases when the volatility index increases and vice versa. Because the objective of this paper is to study the impact of the volatility index on the CDS spreads in emerging markets, our interested coefficient is $c_{1}$. Equation (1) shows the long-run relationship between the variables. Nevertheless, investors take daily positions on their portfolios, so it is important to involve the shortrun dynamics into the model. The cointegration models of Johansen and Juselius (1990) and Engle and Granger (1987) among others incorporate short-run dynamics into the model through studying Equation (1) as an error-correction process and put a condition that all the variables be integrated at the same level. Then Pesaran, Shin, and Smith (2001) proposed an error correction and single cointegration approach, where Equation (1) is estimated as a conditional Autoregressive Distributed Lag (ARDL) model. This approach gives valid results regardless of the integration order of variables under study and is more flexible. The approach has the following steps: (a) identifying an unrestricted error correction model; (b) testing if there is a cointegrating relationship; (c) estimating the long-run coefficients.

This approach models linear or symmetric relationships, thus for Equation (1) it means rise and fall in volatility have symmetrical impacts on the CDS spreads. However, studies show that financial time series, as index prices, spreads, and others generally possess nonlinear dynamics (Narayan (2005)), as the downturns may have a different impact than the expansions. Aliyev, Ajayi, and Gasim (2020) find that the impact of volatility shocks is asymmetric, that is the effects of negative shocks on volatility are greater than the effects of positive shocks of the same size. Andersen, et al (2001) suggest that financial time series exhibit excess kurtosis, fatter tail on the left side of the distribution, and temporal persistence in conditional variance. These known facts of financial time series may give erroneous analysis results under linear assumptions. So, the linear ARDL model that assumes symmetric dynamics is not able to model the potential nonlinearity between CDS spreads and volatility movements. That is why we employ a nonlinear approach in this paper.

Shin, Yu, and Greenwood-Nimmo (2014) improved the linear ARDL model of Pesaran et al. (2001) and have proposed a Nonlinear Autoregressive Distributed Lag (NARDL hereafter) model. The NARDL model is able to capture both long-run and short-run and asymmetries in variables under the study while keeping all merits of the linear ARDL model.

We use the NARDL model proposed by Shin et al. (2014) and introduce the following asymmetrical longrun regression:

$$
C D S=\alpha_{0}+\alpha_{1} P O S_{t}+\alpha_{2} N E G_{t}+\epsilon_{t}
$$

Where $\alpha_{0}, \alpha_{1}$, and $\alpha_{2}$ are long-run parameters that will be estimated, and $\epsilon_{t}$ is the white-noise term. $P O S_{t}$ and $N E G_{t}$ values of the VIX index are the parameters of asymmetry in the NARDL model. The values of $P O S_{t}$ and $N E G_{t}$ are modeled with

$$
\begin{aligned}
& \left\{P O S_{t}=\sum_{j=1}^{t} \Delta V I X_{j}^{+}=\sum_{j=1}^{t}\left(\Delta V I X_{j}, 0\right)\right. \\
& \text { and } N E G_{t}=\sum_{j=1}^{t} \quad \Delta V I X_{j}^{-}=\sum_{j=1}^{t}\left(\Delta V I X_{j}, 0\right)
\end{aligned}
$$

where $\mathrm{POS}_{t}$ is a partial sum of positive changes in VIX, that is increase in volatility, whereas, $N E G_{t}$ is a partial sum of negative changes in VIX which is a positive sign for investors.

The NARDL model estimation has 3 steps: (a) in the first stage, here the Equation (2) is estimated using OLS; (b) the next step is testing whether there is any nonlinear long-run cointegration between the variables. For this purpose, Shin et al. (2014) propose an F-test that tests the null hypothesis of no cointegration against the alternative of cointegration. (c) In the last step, short-run and long-run symmetry are tested using the Wald test.

As discussed above financial time series exhibit asymmetries, thus an increase in volatility may asymmetrically affect CDS spreads. This impact is tested by estimating the $\alpha_{1}$ and $\alpha_{2}$ parameters in the Equation 2. If $\alpha_{1}=\alpha_{2}$ we conclude that there is no asymmetry between CDS spread and the VIX. If, $\alpha_{1} \neq \alpha_{2}$ then we 
find that there is a nonlinear relation between the abovementioned variables.

\section{EMPIRICAL FINDINGS AND DISCUSSIONS}

Due to the requirement of bounds testing, first, we check the all-time series for unit root on the second difference to make sure that not any I (2) variables are involved. Following Enders and Lee (2012)'s suggestion, we use Augmented Dickey and Fuller (1981) test and Phillips and Perron (1988) unit root test. Unit root tests results are reported in Table 2, and it shows that none of the variables is I (2).

Table 2: Unit Test Results

\begin{tabular}{ccc}
\hline Series & ADF & Phillips-Perron \\
\hline VIX & -21.027 & -458.936 \\
\hline CDS_CH & -19.299 & -224.586 \\
\hline CDS_RU & -21.954 & -535.445 \\
\hline CDS_BR & -21.547 & -436.816 \\
\hline CDS_TR & -20.837 & -758.013 \\
\hline CDS_MX & -20.500 & -545.422 \\
\hline
\end{tabular}

Following Alqaralleh (2020) we check for cointegration between CDS and VIX, we apply the Wald test, and find joint $F$-statistics to exceed the $95 \%$ upper critical bounds confirming cointegration. And we apply the Wald tests for symmetry to check for possible asymmetric dynamics. Table 3 summarizes the bound tests and Wald tests results.

Table 3: Bound and Asymmetry Test Results

\begin{tabular}{lcccc}
\hline \multirow{2}{*}{ Country } & \multicolumn{2}{c}{ Bound Test Results } & \multicolumn{2}{c}{ Asymmetry Test Results } \\
\cline { 2 - 5 } & F-statistic & Result & F-statistic & Result \\
\hline$C D S \_C H$ & 11.047 & Cointegrated & 7.031 & Asymmetric \\
\hline$C D S \_R U$ & 6.346 & Cointegrated & 10.509 & Asymmetric \\
\hline$C D S \_B R$ & 5.268 & Cointegrated & 9.505 & Asymmetric \\
\hline$C D S \_T R$ & 19.048 & Cointegrated & 8.382 & Asymmetric \\
\hline$C D S \_M X$ & 12.147 & Cointegrated & 23.660 & Asymmetric \\
\hline
\end{tabular}

The critical values are obtained from Pesaran et al. (2001), assuming unrestricted intercept and unrestricted trend case.

Moreover, we check nonlinearity with the $L M$ test proposed by Luukkonen, Saikkonen, and Teräsvirta (1988), and $L M$ tests reject the linearity in the significant degrees of $1 \%, 5 \%$ and $\% 10$ for various series. As seen from the Wald test for symmetry on the right two columns of Table 3, the NARDL model is an appropriate model rather than the standard ARDL model. After deciding the suitable model, we then estimate the parameters of the NARDL model. The main findings

Table 4: NARDL Estimation Results

\begin{tabular}{|c|c|c|c|c|c|}
\hline Variables & China & Russia & Brazil & Turkey & Mexico \\
\hline \multicolumn{6}{|l|}{ Short-run relations } \\
\hline$\triangle V I X \_P O S$ & $0.2815^{*}$ & $1.4237^{*}$ & $1.4932 *$ & $1.2845^{*}$ & $1.1938^{*}$ \\
\hline$\triangle V I X \_N E G$ & $1.7787^{*}$ & $2.3277^{*}$ & $1.7260^{*}$ & $1.9188^{*}$ & $1.4523^{*}$ \\
\hline$\triangle V I X \_N E G(-1)$ & $0.6141^{*}$ & $0.6093^{*}$ & - & $0.4043^{* *}$ & - \\
\hline$\triangle V I X \_N E G(-3)$ & -0.3222 & - & $-0.2973^{* *}$ & - & - \\
\hline$\triangle V I X \_P O S(-1)$ & $0.4535^{*}$ & $0.5795^{*}$ & - & $0.3505^{* *}$ & - \\
\hline$\triangle V I X \_P O S(-2)$ & $0.2619^{*}$ & - & - & - & - \\
\hline$\triangle V I X \_P O S(-3)$ & $0.1508^{* *}$ & $0.5376^{*}$ & $0.2246^{* * *}$ & $0.2983^{* *}$ & - \\
\hline$\triangle C D S(-1)$ & $-0.1027^{*}$ & $0.1341^{*}$ & $0.2421^{*}$ & - & $0.1671^{*}$ \\
\hline$\triangle C D S(-2)$ & - & - & $-0.0484^{*}$ & - & - \\
\hline$\triangle C D S(-3)$ & $0.0500^{* *}$ & $-0.0395^{* *}$ & - & - & $-0.0427^{* *}$ \\
\hline \multicolumn{6}{|l|}{ Long-run relations } \\
\hline $\operatorname{CDS}(-1)$ & $-0.0079^{*}$ & -0.0037 & $-0.0023^{* * *}$ & $0.1460^{*}$ & $-0.0152^{*}$ \\
\hline VIX_POS(-1) & $0.0411^{* *}$ & 0.0458 & 0.0196 & 0.0217 & $0.0975^{*}$ \\
\hline VIX_NEG(-1) & $-0.0409^{*}$ & 0.0455 & 0.0192 & 0.0215 & $0.0960^{*}$ \\
\hline Constant & $0.7036^{* *}$ & $0.9388^{* *}$ & 0.2129 & 0.2170 & $1.6806^{*}$ \\
\hline
\end{tabular}

Significance levels are denoted with ${ }^{*},{ }^{* *}$ and ${ }^{* * *}$ as $1 \%, 5 \%$ and $10 \%$ respectively.

The negative numbers in parentheses are lag lengths. 
from the analysis are reported in Table 4. The overview of results shows the asymmetrical impact of the VIX index changes on the CDS spreads of the selected markets. Level or lagged VIX index variables are statistically significant in explaining CDS spreads of the selected emerging markets.

As shown on the short-run relations panel of Table 4 , there is an asymmetric impact of the VIX index on the CDS spread of China. That means decreases in the volatility impact CDS spread of China more than an increase in volatility (1.7787 vs. 0.2815$)$. The lagged impact of a decrease in volatility $\left(\triangle V I X \_N E G(-1)\right)$ has near the same magnitude on the spread. However, the impact of lagged increase ( $\left.\triangle V I X \_P O S(-1)\right)$ in volatility is lower than the negative impact. Such different coefficients that are, asymmetry in the short-run is observed in third lagged variables as well. The short-run relation is asymmetric for Russian CDS spread as well. The coefficient of decrease in volatility $\left(\triangle V I X \_N E G\right)$ is higher than the increase. However, in the first lagged variable the relation is near symmetric. Brazilian CDS spread has an asymmetric relationship with the VIX index as well. Negative shocks in the volatility have a higher impact than positive shocks. Such relation was also observed in the third lag. Turkish CDS and the VIX index relation in the short-run are asymmetric as well. As seen from the Turkey column of Table 4, $1 \%$ positive change in the VIX index results \%1.2845 increases in the CDS spread of Turkey, yet $1 \%$ negative change makes $\% 1.9188 \mathrm{dec}-$ rease in the CDS. The Mexican part of the analysis shows the negative changes in the VIX index have a different coefficient than positive changes, and the magnitude is somehow near. The latter expands the findings of Pan and Singleton (2008) for Mexico.

Long-run asymmetric relations are evident in Chinese, Turkish, and Mexican at $1 \%$ significance level and Brazilian CDS spreads at a $10 \%$ significance level. It is not found long-run asymmetry between VIX and Russian CDS spread. To generalize, the relation between the VIX index and CDS spreads of the emerging markets under the study is short-run biased rather than long-run. Long-run lagged positive VIX has the highest impact on the CDS spread of Mexico among other countries in the study.

The robustness of the model is checked with diagnostic tests and reported in Table 5. The series has passed adequacy tests as there is no ARCH effect, no serial correlation and no parameter instability and the model is homoscedastic. Thus, we conclude that the NARDL model employed in the study is well specified.
Table 5: Diagnostic Tests

\begin{tabular}{cccc}
\hline & ARCH effect & $\begin{array}{c}\text { Serial Correlation } \\
\left(\mathrm{X}^{2}-\mathrm{LM}\right)\end{array}$ & $\begin{array}{c}\text { Heteroscedasticity } \\
\left(\mathrm{X}^{2}-\mathrm{H}\right)\end{array}$ \\
\hline China & {$[0.1656]$} & {$[0.2724]$} & {$[0.0195]$} \\
\hline Russia & {$[0.0859]$} & {$[0.1319]$} & {$[0.0026]$} \\
\hline Brazil & {$[0.2032]$} & {$[0.1530]$} & {$[0.0000]$} \\
\hline Turkey & {$[0.1085]$} & {$[0.0946]$} & {$[0.0680]$} \\
\hline Mexico & {$[0.0491]$} & {$[0.2215]$} & {$[0.0327]$} \\
\hline
\end{tabular}

$F$ statistic probability values in parentheses.

\section{CONCLUSION}

This paper studies the nonlinear nexus between sovereign credit risk, namely credit default swap (CDS) of selected emerging markets, and the volatility index (VIX). The findings may lead investors who plan to invest sovereign bonds of the countries under study. So, analyzing the relationship between 5-years CDS spreads of China, Russia, Brazil, Turkey, and Mexico and the VIX index considering asymmetric dynamics is of great importance. The emerging markets are characterized by higher volatility, and asymmetric price falls compared to developed markets. Moreover, financial time series exhibit excess kurtosis, negative skewness, and temporal persistence in conditional variance and other nonlinear patterns. Standard linear models are incapable to capture these nonlinear characteristics of financial series. To this end, we employ the Nonlinear Autoregressive Distributed Lag (NARDL) model which is capable of capturing asymmetric dynamics in the conditional mean of the series.

The study finds negative shocks in a volatility index have a long-lasting impact on CDS spreads of China, Russia, Brazil, Turkey, and Mexico. In other words, the impact of the volatility index shocks is asymmetric at these markets, and that means the effect of negative volatility index shocks on CDS spreads are higher than positive shocks of the same magnitude. Specifically, Chinese CDS spreads are more sensitive to VIX index changes in the short run. The effect of a decrease in volatility on Russian CDS is higher than the effect of an increase. However, the relation in the first lag is almost symmetric. Interestingly, we could not find a long-run asymmetry between VIX and Russian CDS spread. Turkish and Brazilian CDS spreads are more sensitive to rise in the VIX, whereas Mexican CDS spread is a bit less sensitive.

Furthermore, the findings of this research have suggestions for global investors, portfolio managers, 
arbitrageurs and other market participants. Understanding the existence of asymmetries between the global factor of VIX and CDS spreads they may improve their asset allocation, portfolio diversification, credit risk management and hedging decisions on their investments. Our findings propose that watching the VIX index, they may buy or sell the government bonds of these countries, and they must consider that the relationship is asymmetric. In addition, policymakers should consider these dynamics in their decisions about sovereign borrowing.
The limitations of the study are related with data insufficiency of Indonesia and India from E7 countries, thus we omitted these countries. However, considering a large group of countries would result in wider implications. We think future studies should explore other global and country-specific variables factors to rule out the impact of volatility on sovereign credit risk. Moreover, coming studies may consider using regime switching models to explore the nexus between sovereign credit risk and global factors. 


\section{REFERENCES}

Agliardi, E., Agliardi, R., Pinar, M., Stengos, T., \& Topaloglou, N. (2012). A new country risk index for emerging markets: A stochastic dominance approach. Journal of Empirical Finance, 19(5), 741-761.

Aliyev, F. (2019). Testing market efficiency with nonlinear methods: Evidence from Borsa Istanbul. International Journal of Financial Studies, 7(2), 27.

Aliyev, F., Ajayi, R., \& Gasim, N. (2020). Modelling asymmetric market volatility with univariate GARCH models: Evidence from Nasdaq-100. The Journal of Economic Asymmetries, 22, e00167.

Alqaralleh, Huthaifa (2020). Stock return-inflation nexus; revisited evidence based on nonlinear ARDL Journal of Applied Economics, 23(1), 66-74.

Andersen, T. G., Bollerslev, T., Diebold, F. X., \& Ebens, H. (2001). The distribution of realized stock return volatility. Journal of Financial Economics, 61(1), 43-76.

Ballester, L., \& González-Urteaga, A. (2017). How credit ratings affect sovereign credit risk: Cross-border evidence in Latin American emerging markets. Emerging Markets Review, 30, 200-214.

Borri, N., \& Verdelhan, A. (2011). Sovereign risk premia. Paper presented at the AFA 2010 Atlanta Meetings Paper.

Cantor, R., \& Packer, F. (1996). Sovereign risk assessment and agency credit ratings. European Financial Management, $2(2), 247-256$.

Chan-Lau, J. A., \& Kim, Y. S. (2004). Equity prices, credit default swaps, and bond spreads in emerging markets (WP/04/27).

Chan, K. C., Fung, H.-G., \& Zhang, G. (2009). On the relationship between asian sovereign credit default swap markets and equity markets. Journal of Asian Business Studies, 4(1), 3-12.

Chuffart, T., \& Hooper, E. (2019). An investigation of oil prices' impact on sovereign credit default swaps in Russia and Venezuela. Energy Economics, 80, 904-916.

Dickey, D. A., \& Fuller, W. A. (1981). Likelihood ratio statistics for autoregressive time series with a unit root. Econometrica: Journal of the Econometric Society, 49(4), 1057-1072.

Enders, W., \& Lee, J. (2012). The flexible Fourier form and Dickey-Fuller type unit root tests. Economics Letters, 117(1), 196-199.

Engle, R. F., \& Granger, C. W. (1987). Co-integration and error correction: representation, estimation, and testing. Econometrica: Journal of the Econometric Society, 55(2), 251-276.

Eyssell, T., Fung, H.-G., \& Zhang, G. (2013). Determinants and price discovery of China sovereign credit default swaps. China Economic Review, 24, 1-15.

Figuerola-Ferretti, I., \& Paraskevopoulos, I. (2013). Pairing market risk and credit risk. Available at SSRN 1553863.

Harvey, C. R. (1995). Predictable risk and returns in emerging markets. The Review of Financial Studies, 8(3), 773-816.
Hilscher, J., \& Nosbusch, Y. (2010). Determinants of sovereign risk: Macroeconomic fundamentals and the pricing of sovereign debt. Review of Finance, 14(2), 235-262.

Ismailescu, I., \& Kazemi, H. (2010). The reaction of emerging market credit default swap spreads to sovereign credit rating changes. Journal of Banking \& Finance, 34(12), 2861-2873.

Jeanneret, A. (2015). The dynamics of sovereign credit risk. Journal of Financial and Quantitative Analysis, 50(5), 963-985.

Johansen, S., \& Juselius, K. (1990). Maximum likelihood estimation and inference on cointegration-with appucations to the demand for money. Oxford Bulletin of Economics and Statistics, 52(2), 169-210.

Larraín, G., Reisen, H., \&Von Maltzan, J. (1997). Emerging market risk and sovereign credit ratings. OECD Development Centre Working Paper, 124, 1-30.

Longstaff, F. A., Pan, J., Pedersen, L. H., \& Singleton, K. J. (2011). How sovereign is sovereign credit risk? American Economic Journal: Macroeconomics, 3(2), 75-103.

Luukkonen, R., Saikkonen, P., \& Teräsvirta, T. (1988). Testing linearity against smooth transition autoregressive models. Biometrika, 75(3), 491-499.

Maltritz, D., \& Molchanov, A. (2014). Country credit risk determinants with model uncertainty. International Review of Economics \& Finance, 29, 224-234.

Merton, R. C. (1974). On the pricing of corporate debt: The risk structure of interest rates. The Journal of Finance, 29(2), 449470.

Narayan, P. K. (2005). The saving and investment nexus for China: evidence from cointegration tests. Applied Economics, 37(17), 1979-1990.

Pan, J., \& Singleton, K. J. (2008). Default and recovery implicit in the term structure of sovereign CDS spreads. The Journal of Finance, 63(5), 2345-2384.

Patel, S. A., \& Sarkar, A. (1998). Crises in developed and emerging stock markets. Financial Analysts Journal, 54(6), 50-61.

Pesaran, M. H., Shin, Y., \& Smith, R. J. (2001). Bounds testing approaches to the analysis of level relationships. Journal of Applied Econometrics, 16(3), 289-326.

Phillips, P. C., \& Perron, P. (1988). Testing for a unit root in time series regression. Biometrika, 75(2), 335-346.

Remolona, E. M., Scatigna, M., \&Wu, E. (2008). The dynamic pricing of sovereign risk in emerging markets: Fundamentals and risk aversion. The Journal of Fixed Income, 17(4), 57-71.

Ricciardi, A. (2016). Exploiting the cointrgration between VIX and CDS in a credit market timing model.Unpublished Doctoral Dissertation.

Shahzad, S. J. H., Nor, S. M., Ferrer, R., \& Hammoudeh, S. (2017). Asymmetric determinants of CDS spreads: US industry-level evidence through the NARDL approach. Economic Modelling, 60, 211-230. 
Shin, Y., Yu, B., \& Greenwood-Nimmo, M. (2014). Modelling asymmetric cointegration and dynamic multipliers in a nonlinear ARDL framework. In R. C. Sickles \& W. C. Horrace (Eds.), Festschrift in Honor of Peter Schmidt (pp. 281-314). New York, NY: Springer.

Sturzenegger, F., \& Zettelmeyer, J. (2006). Debt Defaults and Lessons from a Decade of Crises: MIT Press.
Weigel, D. D., \& Gemmill, G. (2006). What drives credit risk in emerging markets? The roles of country fundamentals and market co-movements. Journal of International Money and Finance, 25(3), 476-502. 